\title{
Changes in Holocene climate and the intensity of Southern Hemisphere Westerly Winds based on a high-resolution palynological record from sub-Antarctic South Georgia
}

The Holocene

20I5, Vol. 25(2) 263-279

(C) The Author(s) 2014

Reprints and permissions: sagepub.co.uk/journalsPermissions.nav DOI: I0.I I77/09596836|4557576 hol.sagepub.com

\author{
Stephanie L Strother,' Ulrich Salzmann,' Stephen J Roberts, ${ }^{2}$ \\ Dominic A Hodgson, ${ }^{2}$ John Woodward,' Wim Van Nieuwenhuyze, ${ }^{3}$ \\ Elie Verleyen, ${ }^{3}$ Wim Vyverman ${ }^{3}$ and Steven G Moreton ${ }^{4}$
}

\begin{abstract}
Sub-Antarctic South Georgia is a key region for studying climate variability in the Southern Hemisphere, because of its position at the core of the Southern Hemisphere Westerly Wind belt and between the Antarctic Circumpolar Current and the Polar Frontal Zone. Here, we present a 5.8-m long highresolution pollen record from Fan Lake on Annenkov Island dominated by local sub-polar vegetation, with Acaena and Poaceae being present throughout the last 7000 years. Palynological and sedimentological analyses revealed a warm late Holocene 'climate optimum' between 3790 and 2750 cal. yr BP, which was followed by a gradual transition to cool and wet conditions. This cooling was interrupted by slightly warmer environmental conditions between 1670 and 710 cal. yr BP that partly overlap with the Northern Hemisphere 'Medieval Climate Anomaly'. Increases in non-native and long-distance pollen grains transported from South America (e.g. Nothofagus, Podocarpus) indicate that stronger Southern Hemisphere Westerly Winds over South Georgia possibly occurred during some 'colder' phases of the late Holocene, most notably between c. 2210 and I670 cal. yr BP and after 710 cal. yr BP.
\end{abstract}

\section{Keywords}

Holocene, palynology, South Georgia, Southern Hemisphere Westerly Winds, sub-Antarctica, vegetation

Received 10 June 2014; revised manuscript accepted 22 September 2014

\section{Introduction}

The mid- to late Holocene climate of the Southern Hemisphere high latitudes is characterised by an early Holocene warm period from 11,000 to 9500 cal. yr BP, a general cooling until $4500 \mathrm{cal}$. yr BP and a mid-late Holocene warm period from 4500 to 2800 cal. yr BP or later (Bentley et al., 2009). Following this, a cooler period generally persisted until the present rapid regional warming of the last few decades with many regional variations (Hodgson et al., 2009).

The mid-late Holocene warm period in the Antarctic Peninsula region has been attributed to increases in solar insolation (Bentley et al., 2009) and changes in the meridional position of the core of the Southern Hemisphere Westerly Wind (SHW) belt. Understanding the link between climate changes and the position and strength in the SHW in this region is important because changes in the winds can affect upwelling in the Southern Ocean, which in turn affects global $\mathrm{CO}_{2}$ levels (e.g. Anderson et al., 2009; Björck et al., 2012; Hodgson and Sime, 2010; Le Quéré et al., 2010; Watson and Garabato, 2006). Multiple climate model simulations (Varma et al., 2012) suggest an overall strengthening and poleward shifting trend in the SHW during the course of the mid- to late Holocene corresponding with a cooling trend in Antarctica (Masson et al., 2000). However, validating the model results with reconstructions of the past position and intensity of the SHW still remains elusive. For example, Varma et al. (2012) note that proxy records from western Patagonia (Moreno et al., 2010) suggest a trend of increasing SHW strength during the past 7000 years, which is not supported by sedimentological and pollen-based reconstructions of precipitation variability in South Patagonia (see Fletcher and Moreno, 2012; Lamy et al., 2010).

These studies highlight a limitation of many high-latitude palaeoclimate records which show considerable variability not only in the timing of inferred warm and cool periods (which is further

'Department of Geography, Faculty of Engineering and Environment, Northumbria University, UK

${ }^{2}$ British Antarctic Survey, UK

${ }^{3}$ Laboratory of Protistology and Aquatic Ecology, Ghent University, Belgium

${ }^{4}$ National Environment Research Council Radiocarbon Facility, UK

Corresponding author:

Stephanie L Strother, Department of Geography, Faculty of Engineering and Environment, Northumbria University, Newcastle upon Tyne, NEI 8ST, UK.

Email: stephanie.strother@northumbria.ac.uk 
compounded by low resolution age control in many studies; Table 1), but also in differences in the precise climate forcing mechanisms used to explain them. In the core belt of the SHW, the lack of reliable reconstructions is particularly acute because of the limited amount of landmasses from which palaeoclimate records can be obtained. These landmasses consist of the southernmost tip of South America and a small number of islands in the sub-Antarctic region. Even at these locations, local orographic, glaciological and edaphic factors can overprint the regional climate signals.

Here, we present a well-dated, high-resolution pollen record of mid- to late Holocene vegetation and climate change from a lake sediment core from Fan Lake, Annenkov Island, South Georgia (Figure 1). The South Georgia archipelago lies in the core belt of the SHW, and its climate is governed by the latitudinal movement of the Polar Front Zone (PFZ) and the SHW (Bentley et al., 2007), which makes it particularly sensitive to even relatively minor climatic fluctuations. Most existing palaeorecords have been taken from the north and northeastern side of South Georgia (Bentley et al., 2007; Rosqvist and Schuber, 2003), but sites off the southwest coast, such as Annenkov Island, are thought to be particularly responsive because they are not affected by active glaciation, or orographic influences prevalent on the northeastern sites.

The overall aims of our project were (1) to establish when Annenkov Island was last glaciated, (2) to assess whether the timing and extent of any periods of Holocene glacier advance were synchronous or offset with known phases of glacier advance on mainland South Georgia and (3) to test the hypothesis that Holocene palaeoenvironmental change on Annenkov Island is more directly coupled to changes in the SHW circulation compared with sites elsewhere on South Georgia that are influenced by orographic effects. The first two aims are addressed further in forthcoming papers. In this paper, our aims were to identify long-term regional changes in climate and vegetation and to test whether long-distance pollen influx at Fan Lake is related to previously reconstructed changes in SHW circulation.

\section{Site and present day vegetation}

South Georgia is located in the South Atlantic Ocean approximately $1300 \mathrm{~km}$ east-southeast of the Falklands Islands (Figure 1). The island is $\sim 170 \mathrm{~km}$ long with mountains (Allardyce Range) reaching up to $2000 \mathrm{~m}$ down the middle of the island (Bentley et al., 2007; Rosqvist and Schuber, 2003). Meteorological records from King Edward Point show well-defined summer and winter seasons (Barrow, 1978) on the north coast of South Georgia with a mean annual temperature of $2^{\circ} \mathrm{C}$ (Van der Putten et al., 2004) and a mean annual precipitation of around $1400 \mathrm{~mm}$ at sea level (Rosqvist and Schuber, 2003). South Georgia is positioned at the maximum northern limit of Antarctic pack ice, and over half the island is permanently covered in glaciers and ice fields (Bentley et al., 2007).

Annenkov Island $\left(54^{\circ} 29^{\prime} \mathrm{S}-55^{\circ} 00^{\prime} \mathrm{S}, 35^{\circ} 30^{\prime} \mathrm{W}-38^{\circ} 30^{\prime} \mathrm{W}\right.$; Figure 1) is situated c. $15 \mathrm{~km}$ off the mid-south-west coast of South Georgia. Although it rises to $640 \mathrm{~m}$ (Olstad Peak; Figure 1c), no permanent snow or ice cover remains (Barrow, 1983). Fan Lake is one of two large permanent lakes on Annenkov Island. The lake is $c .430 \mathrm{~m}$ long, $200 \mathrm{~m}$ wide and located c. $90 \mathrm{~m}$.a.s.l. on the southeastern corner of Annenkov Island (Pettigrew, 1981). The lake catchment consists of a shallow U-shaped valley surrounded by a series of ridges, which become progressively less vegetated with altitude (Figure 1d). There are several streams entering the lake, possibly changing course across the vegetated fan area through time. There is a small inflow through a peat land covered gravel delta at the western end, and at the eastern end an outflow stream cuts through two prominent sets of bedrock ridges and a landscape of hummocks and hollows filled by peat land. Pettigrew (1981) described glacial till exposed by the outflow stream from Fan Lake, but from our observations, this could also be heavily vegetated weathered bedrock. A steep, partially vegetated scree slope on the northern side of the lake is composed of fine-grained mudstone, which outcrops on a small hill to the north of the fault line. A waterfall-stream also enters the lake on the northern edge.

Cores were extracted from the deepest point of Fan Lake $(18 \mathrm{~m})$ and from the centre of a peat land area (henceforth referred to as $\mathrm{KH} 4 ; 54^{\circ} 29.927^{\prime} \mathrm{S}, 37^{\circ} 02.876^{\prime} \mathrm{W}$ ) c. $50 \mathrm{~m}$ from the eastern outflow stream. The latter was used to better constrain the local deglaciation history of the site.

The vegetation in the region is dominated by sub-Antarctic herbs and shrubs such as Acaena spp. (Acaena magellanica, A. magellanica $\times$ Acaena tenera, A. tenera), Colobanthus spp. (Colobanthus quitensis, Colobanthus subulatus) and Callitriche antarctica (Greene, 1969; Greene and Walton, 1975). A. magellanica herbfields are found in sheltered areas, while Colobanthus spp. is frequent in rock face and fellfield communities on Annenkov Island (Barrow, 1983). Grasslands (Poa flabellata) are abundant throughout South Georgia (Barrow, 1978; Greene, 1969). Ferns such as Polypodium australe, Grammitis kerguelensis, Hymenophyllum falklandicum, Blechnum penna-marina and the clubmoss Lycopodium magellanicum are found in some quantity (Greene, 1969; Greene and Walton, 1975). Montia fontana, a wet flush species, Ranunculus biternatus and C. antarctica, a waterstarwort plant, are found in wetter environments on South Georgia (Barrow, 1983).

One potential problem of reconstructing past vegetation on South Georgia is the selective preservation of pollen produced by some species. For example, while the flowering plants, Juncus (Juncus inconspicuous, Juncus scheuchzerioides) and Rostkovia magellanica are two of the most common native species (Greene, 1969; Van der Putten et al., 2010), the pollen are not preserved in fossil assemblages (Van der Putten et al., 2004).

South Georgia experienced little or no human activity until the establishment of sealing and whaling stations on the north coast of the island during the last c. 150 years (Barrow, 1978). As a result of these human impacts, a number of introduced plant species are present, but in many cases, these are restricted to the areas around the abandoned whaling stations (Osborne et al., 2009). Currently, 62 introduced species have been recorded on South Georgia (Osborne et al., 2009), but they are less pervasive on Annenkov Island because of the infrequency of human visitation. For some species, such as members of the Asteraceae, it remains unclear whether they were introduced or are native to the region (Birnie, 1990; Osborne et al., 2009).

\section{Material and methods}

\section{Sedimentology and chronology}

Sediment cores were extracted from Fan Lake (Figure 1d) using UWITEC gravity and percussion driven piston corers. Two $18-\mathrm{cm}$ UWITEC gravity cores were extracted to recover the near-surface sediments from the main core site and sectioned at $0.5-\mathrm{cm}$ intervals, with a thick moss layer preventing deeper coring. The UWITEC piston corer was deployed to extract deeper sediments in a series of 2-m long offset drives capturing $1.87-1.90 \mathrm{~m}$ of sediment with $20 \mathrm{~cm}$ overlaps to produce a continuous sequence down to $5.8 \mathrm{~m}$, where drilling was stopped by a large rock or bedrock. The cores were photographed (visual and $\mathrm{x}$-radiographic imagery), macroscopically described and analysed for wet density, dry mass $\left(105^{\circ} \mathrm{C}\right.$ for $12 \mathrm{~h}$ ), organic content (loss-on-ignition (LOI) at $550^{\circ} \mathrm{C}$ for $2 \mathrm{~h}$ ) and carbonate composition (LOI at $925^{\circ} \mathrm{C}$ for $2 \mathrm{~h}$, multiplied by 1.36 to provide a first approximation of total carbonate) following standard methods (Dean, 1974). Known overlaps, the main changes in lithology defined initially by density, LOI, Barington Instruments MS2G loop sensor (1 cm sensor, 10-s 


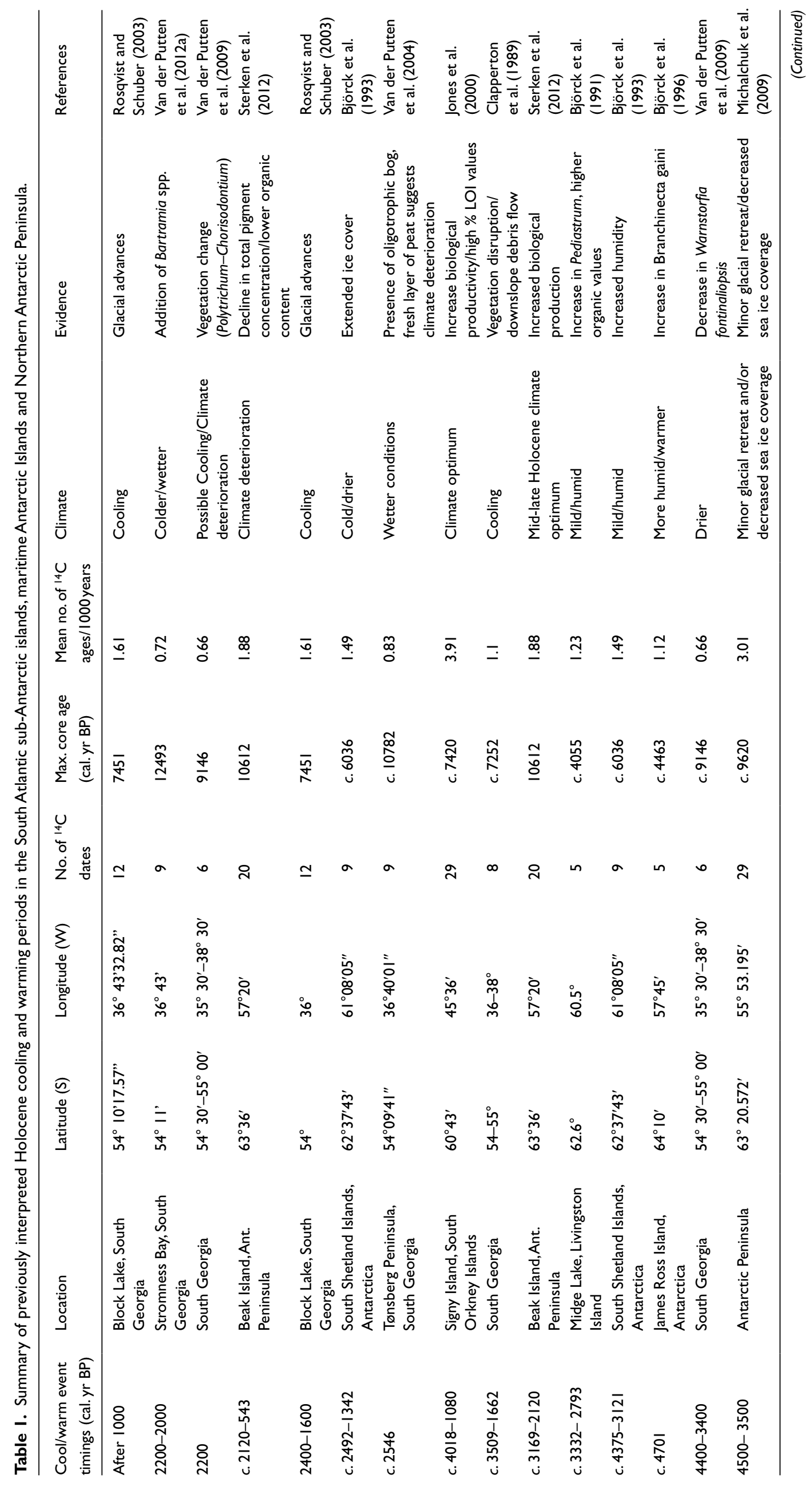




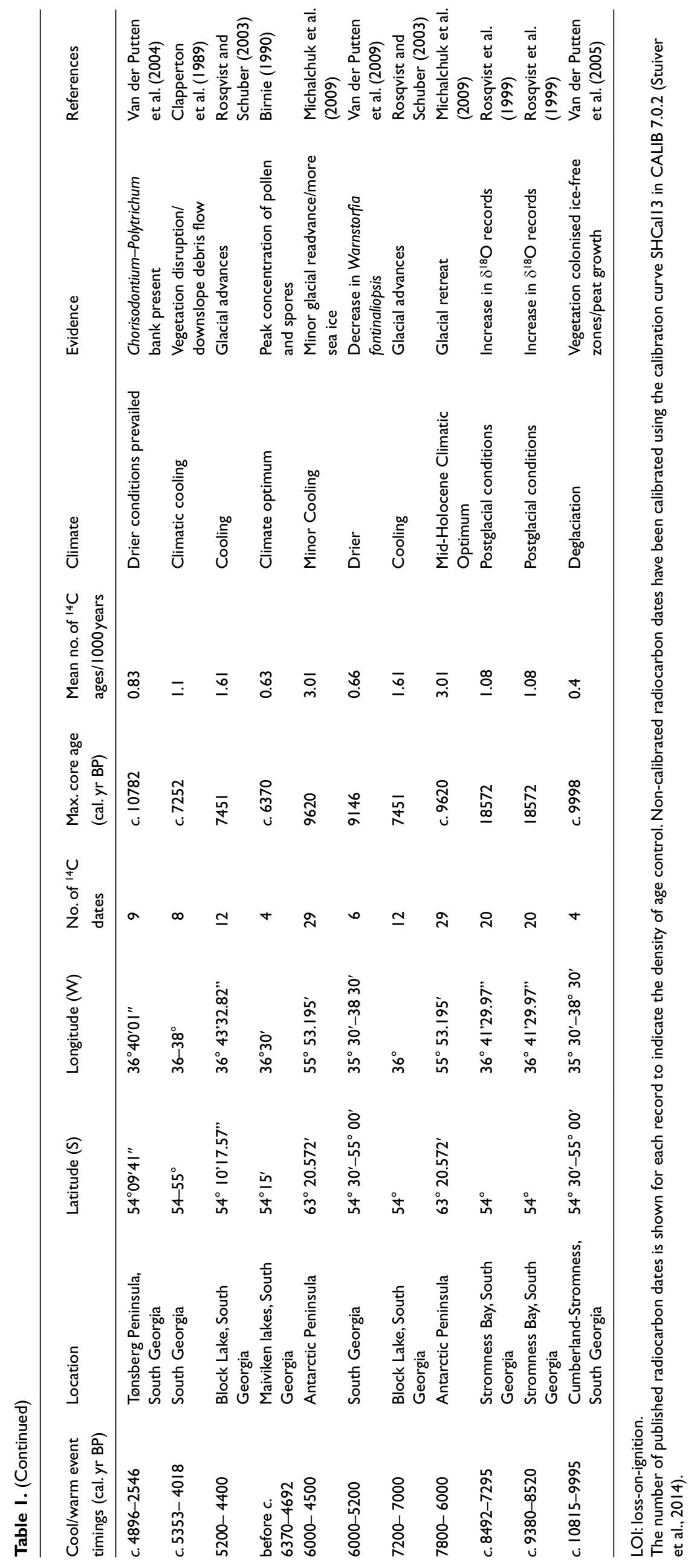




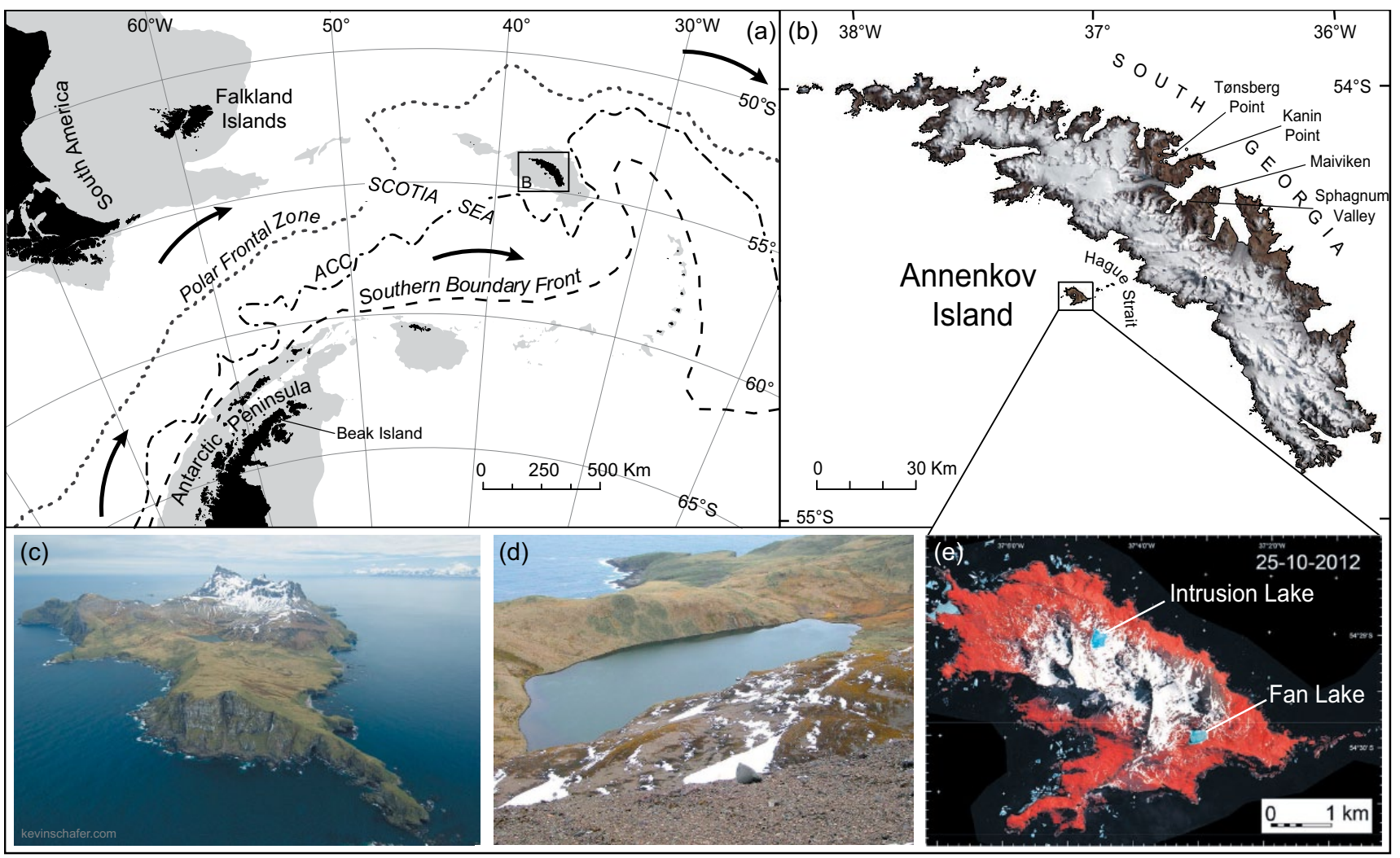

Figure I. (a) Location map of the South Atlantic, showing the location of the main frontal systems of the Southern Ocean influencing the climate of South Georgia, South America and the Antarctic Peninsula. Landmasses are shaded black; areas less than $500 \mathrm{~m}$ deep are shaded grey;ACC:Antarctic Circumpolar Current. (b) LANDSAT image of South Georgia, showing the location of Annenkov Island and place names mentioned in text. (c and d) Fan Lake field site. (e) Satellite image of Annenkov Island. Red colour indicates vegetation cover on 25 October 2012 calculated from very high-resolution Quickbird2 satellite images with an on-the-ground resolution of $2.4 \mathrm{~m}$ per pixel. Live green vegetation in each pixel of the satellite image shows up as red in the image because the cell structure of chlorophyll containing cells absorbs red light while reflecting light in the infra-red part of the spectrum (Fretwell et al., 20II).

measurement time) at 2-mm intervals with standard calibration procedures (Gunn and Best, 1998), were used with the position of visible moss layers and key lithological markers, to stack the five core sections into a single stratigraphic sequence and to produce a composite depth sequence.

Lead-210 $\left({ }^{210} \mathrm{~Pb}\right)$ and Ceasium-137 $\left({ }^{137} \mathrm{Cs}\right)$ dating analysis was undertaken on the upper $11 \mathrm{~cm}$ of the surface core using dried and homogenised samples packed into a $40-\mathrm{mm}$ tube to $40 \mathrm{~mm}$ depth and left to stand for at least 21 days to allow ${ }^{226} \mathrm{Ra}$ and ${ }^{214} \mathrm{~Pb}$ to reach equilibrium. Samples were measured on an Ortec J-shape ultra-low background germanium well detector and remote preamplifier. Data analysis and dating model calculations were undertaken following standard procedures as defined in Appleby (2001). ${ }^{137} \mathrm{Cs}$ was at or below detection limits. Unsupported ${ }^{210} \mathrm{~Pb}$ estimates were derived from both the constant initial concentration (CIC) and constant rate of supply (CRS) method (Table S1, available online) (Appleby and Oldfield, 1978). CRS ages were used in whole core age-depth modelling.

A total of 32 samples for radiocarbon dating were taken from the Fan Lake core. One basal sample from the KH4 peat core was also dated to provide an additional constraint on the timing of catchment deglaciation (Table 2). Calibration of terrestrial radiocarbon ages was carried out in OXCAL v.4.2 (Bronk Ramsey, 2009) using the SHCal13 Southern Hemisphere atmosphere dataset (Hogg et al., 2013). For post-bomb samples, absolute percentage of modern carbon (pMC) data were corrected according to ${ }^{13} \mathrm{C} /{ }^{12} \mathrm{C}$ isotopic ratios from measured $\mathrm{pMC}$, where a 'modern' $\mathrm{pMC}$ value is defined as $100 \%$ ( $\mathrm{AD} 1950$ ), and the 'present day' pMC value is defined as $107.5 \%$ ( $\mathrm{AD} 2010$ ), and calibrated using the SHCal13 SH Zone 1-2 Bomb curve in CALIBomb (Hua et al., 2013; Reimer and Reimer, 2004). As all radiocarbon age errors are less than 50 years, calibrated ages are rounded to the nearest 5 years in Table 2.

A master age-depth model was constructed using a combination of all ${ }^{210} \mathrm{~Pb}$ CRS ages and 32 radiocarbon ages in a Bayesian age-depth model undertaken in BACON v2.2 (Blaauw and Christen, 2011; Figure 2; Table 2). All ages quoted in text are weighted mean ages produced from the BACON age-depth model rounded to the nearest 10 years (Figure 2; Table 2).

\section{Palynological analysis}

Below $92 \mathrm{~cm}$, the core was subsampled at $8-\mathrm{cm}$ increments for pollen analysis. To capture higher resolution changes during the late Holocene, the uppermost $\sim 92 \mathrm{~cm}$ of the core was subsampled at 3- to 4-cm increments.

Approximately $1-2 \mathrm{~g}$ of sediment per sample were run through a $125-\mu \mathrm{m}$ sieve after treatment with $\mathrm{KOH}$ and $\mathrm{HCl}$. Standard laboratory techniques (Fægri and Iversen, 1989) including HF treatment and acetolysis were used to process the pollen samples. A Lycopodium tablet was added to calculate pollen concentrations (Stockmarr, 1971), and samples were mounted with silicone oil. Lycopodium was differentiated between the tablets (Lycopodium clavatum) and the species found on South Georgia (L. magellanicum) because of different reticula (cf. Wilce, 1972). Between 400 and 600 pollen grains were counted per sample, with the exception of the lower portion of the core $(400-587 \mathrm{~cm})$, where the pollen influx dropped significantly. Acaena and Poaceae dominate the entire pollen profile with total percentages between $90 \%$ and 98\%. Barrow (1976, 1978, 1983), Markgraf and D'Antoni (1978), and the pollen reference collection held at Northumbria University was used for pollen and spore identification. Indeterminable 


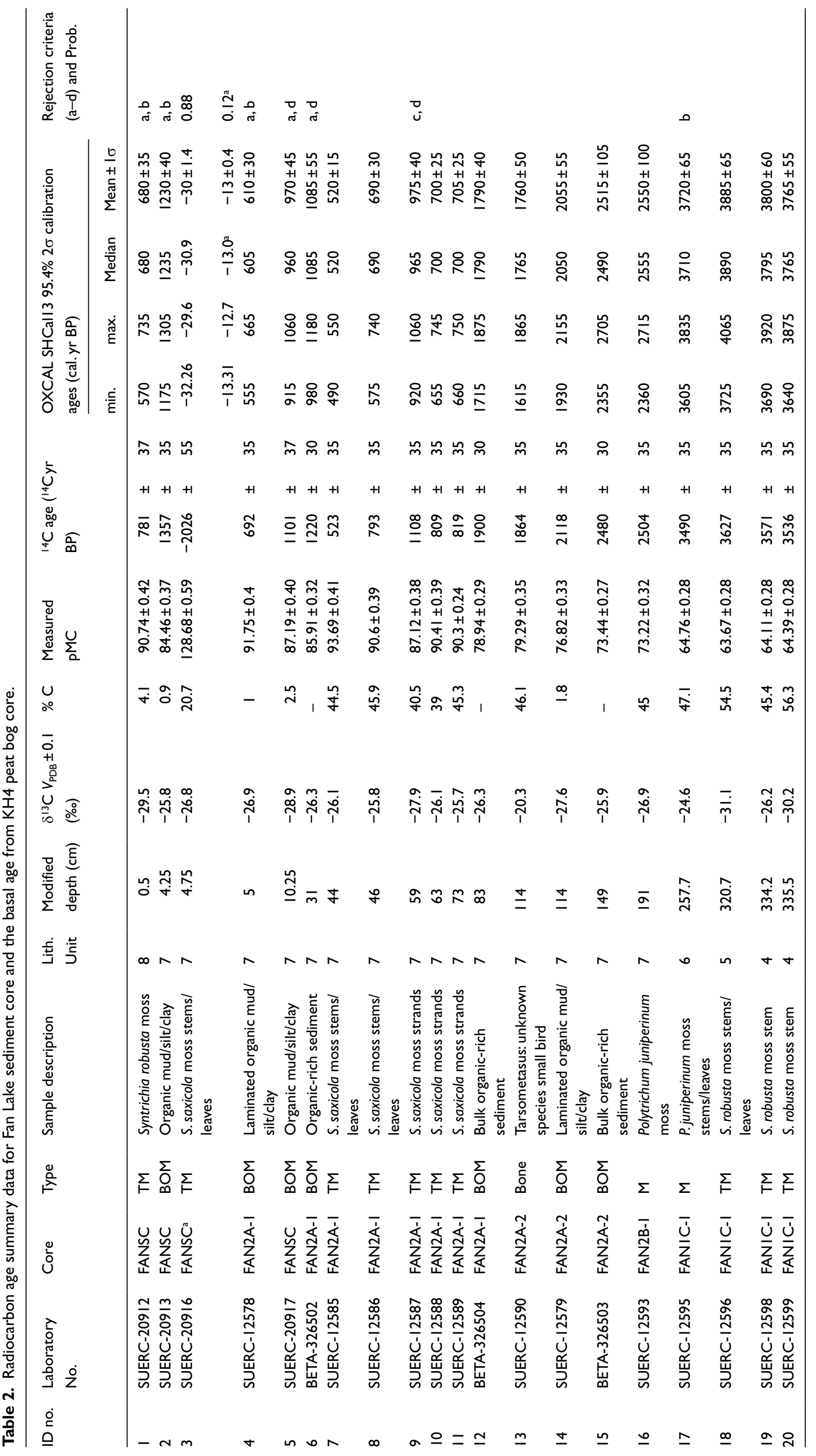




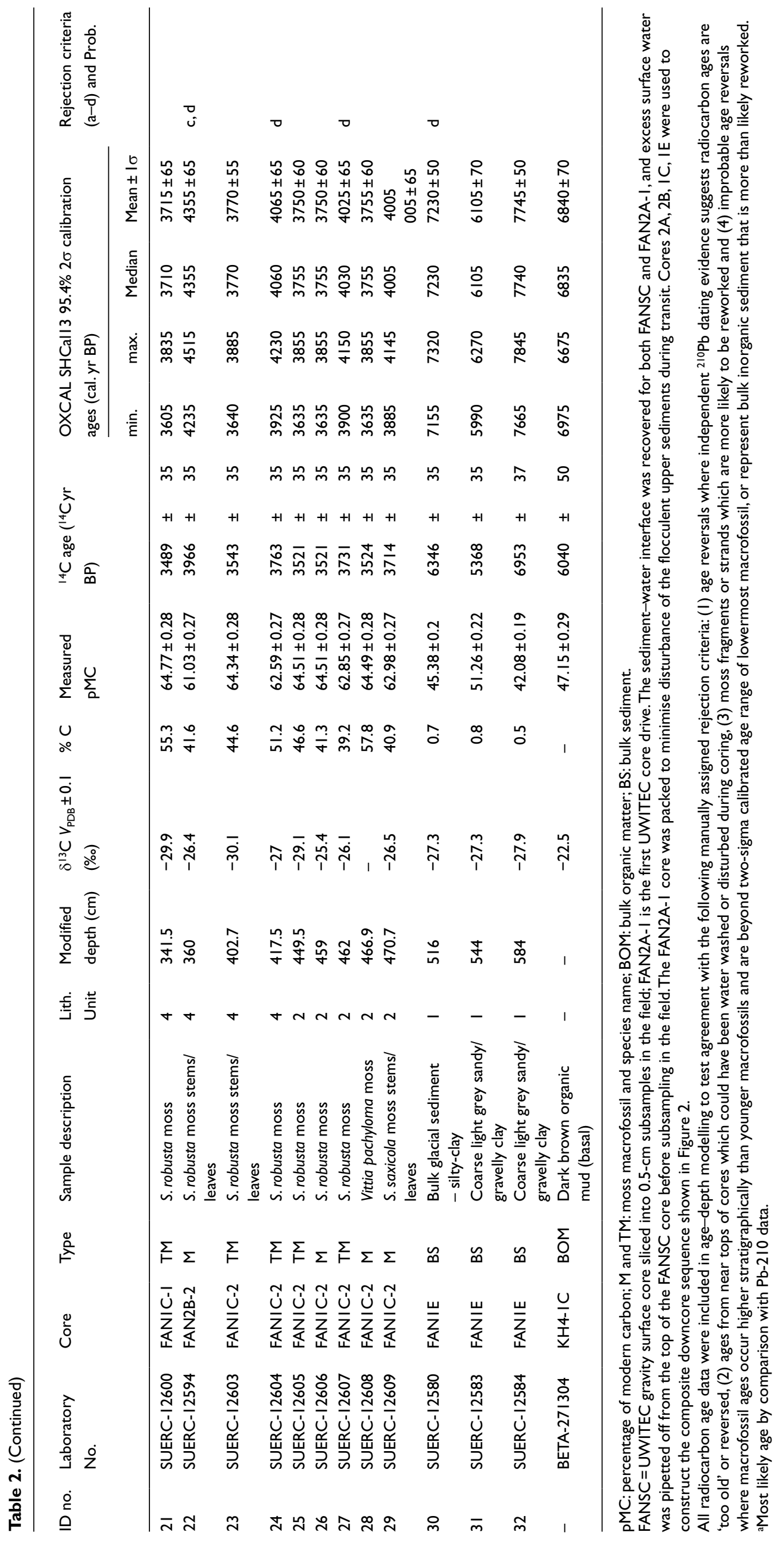




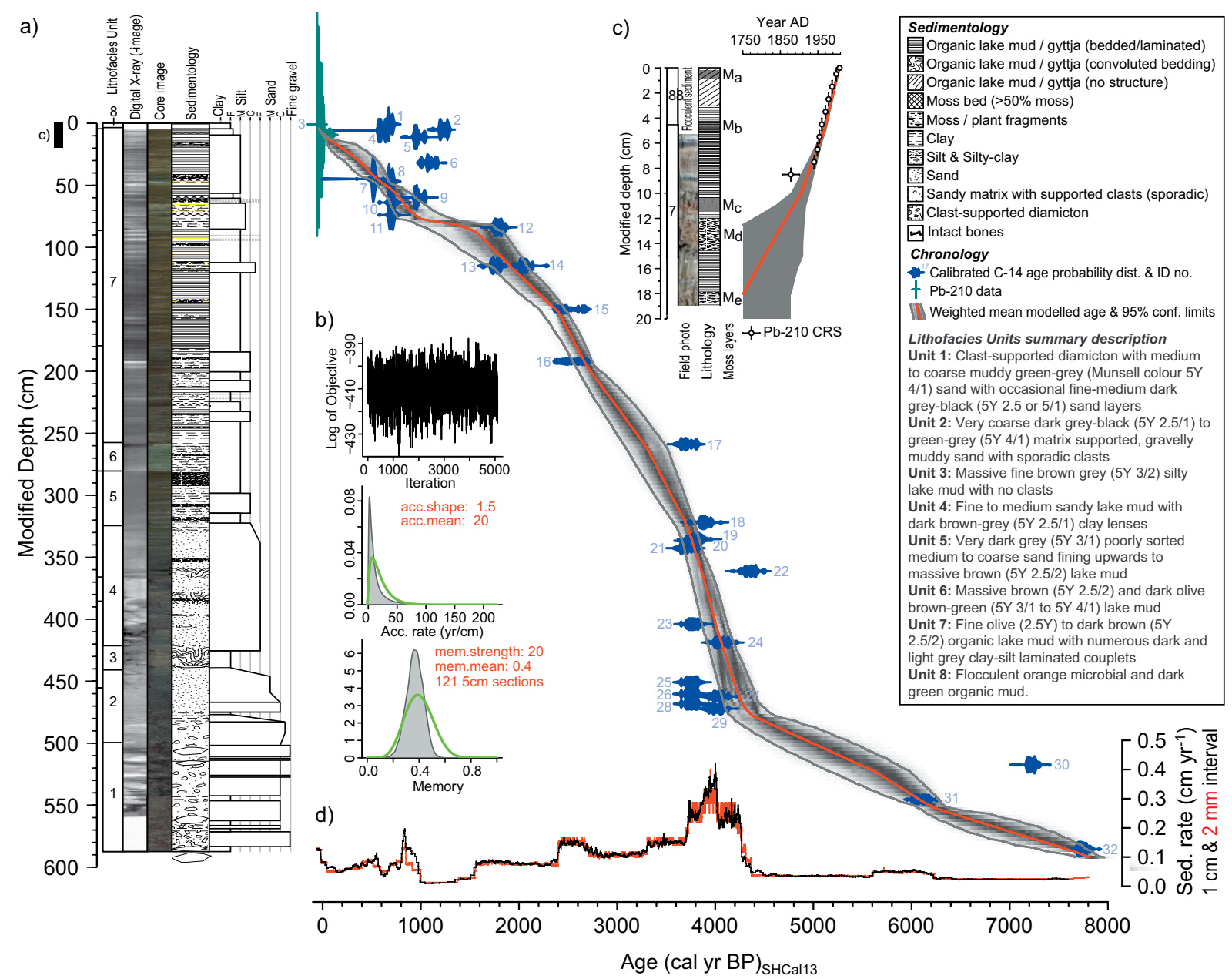

Figure 2. (a) Age-depth model for calculation of down-core radiocarbon ages (see text) compared with visual and x-radiographic core imagery (taken using an ITRAX XRF core scanner; running conditions $50 \mathrm{kV}, 50 \mathrm{~mA}, 200 \mathrm{~ms}, 100 \mu \mathrm{m}$ measurement interval), sedimentology and grain size summary data for the composite Fan Lake core. X-radiographic images are negatives; hence, areas with greater relative density are grey-white and darker areas are more organic or, in Units I-2, represent areas of the core where clasts were removed before scanning.Age-depth modelling was undertaken in BACON v2.2 (Blaauw and Christen, 20I I) using all radiocarbon ages and constant rate of supply (CRS) age model $210 \mathrm{~Pb}$ data (shown as white circles in c; see also Table SI, available online) using the SHCal 3 calibration curve (Hogg et al., 20I3) with 5-cm segments, I2I segments in total, for 27 million iterations and with every 615 th iteration selected. Initial parameters were mean accumulation rate of $20 \mathrm{yr} \mathrm{cm}^{-1}$, accumulation shape $=1.5$, mem. strength $=20$. When tested, mem. strength values of $10-100$ gave essentially the same result, increasing confidence in the model parameters chosen and the reliability of the model. Calibrated age probability distributions with identification numbers are shown in blue. The median best-fit age plot (I-mm interval) in red is superimposed on individual BACON data runs shown as a grey shaded area. Darker grey areas indicate a greater density of individual age-depth model runs. The solid grey line represents the $95 \%$ confidence age limits for model runs. Colour versions of the core image can be viewed in the online version of this article; (b) Set up parameters for the BACON age-depth model; (c) Pb-2 10 ages ( \pm I-sigma errors) from the CRS model which were used in the whole core age-depth model (red line and grey shading as described in a; (d) Sedimentation rates for the Fan Lake core calculated at $\mathrm{I} \mathrm{cm}$ and $2 \mathrm{~mm}$ intervals.

and damaged pollen grains were used as an indicator for erosion and fluvial sediment transport, based upon these pollen grains becoming indeterminable because of damage by transportation and sediment removal.

The Tilia program was used to produce percentage and influx pollen diagrams (Grimm, 1990) with pollen assemblage zones delimited by stratigraphically constrained cluster analysis in CONISS (Grimm, 1987). The significance of the zones was assessed using a broken-stick model in the Rioja package (Juggins, 2012). The pollen sum that is used to calculate percentage pollen diagrams is the total of pollen, excluding fungal spores and pollen grains derived from long-distance transport.

\section{Multivariate analysis of the pollen data}

Principal components analyses (PCAs) of the Fan Lake pollen data were carried out in PRIMER 6 and PAST (Clark and Gorley, 2006; Hammer et al., 2001). Rare (consistently <1\%) pollen taxa were excluded, and remaining pollen percentages were normalised in PRIMER 6 (Clark and Gorley, 2006) prior to analysis. Confidence intervals $(95 \%)$ were calculated for the total long-distance taxa (Ephedra, Fabaceae undiff., Myrtaceae, Nassauvia, Nothofagus and Podocarpaceae) using Psimpoll version 4.26 (Bennett, 2008). Through this method, changes in long-distance transport from the Fan Lake record are shown by deviation from the overlapping confidence limits indicated by a mean of 1.496 or greater.

\section{Results}

\section{Sedimentology and chronology}

The 587-cm Fan Lake core lithology was divided into eight units (Figure 2), from a basal unit (Unit 1) composed of a clast-supported sandy matrix to the uppermost units, which consist of laminated organic lake muds (Unit 7), capped by a living microbial mat and lake mud deposit (Unit 8; Figure 2). Between c. 587 and $499.5 \mathrm{~cm}$, Unit 1 consists of a dark grey clast-supported diamicton to a dark greyish brown sandy matrix with clasts. Unit 1 grades into Unit 2 (499.5-442 cm), which is predominantly composed of 
dark grey to a very dark greyish brown sandy matrix with clasts. Unit $3(442-424 \mathrm{~cm})$ is a fine organic lake mud, capped by Unit 4 $(424-325 \mathrm{~cm})$, an interbedded, and convoluted unit of sand and fine lake mud. Units 5 and $6(325-257.5 \mathrm{~cm})$ are geochemically similar, but fine upwards from a dark greyish brown silt-rich siltyclay into a light grey/pale yellow clay-rich silty-clay layer. Unit 7 $(257.5-0 \mathrm{~cm})$ comprises finely laminated organic mud, with occasional 2- to 3-cm thick sandy-silt layers. Organic carbon (measured as LOI) increases from $325 \mathrm{~cm}$ towards the top of the core, with maximum values present between 250 and $200 \mathrm{~cm}$.

Reworking of older material appears to have affected some of the bulk ages from glacially derived sediments near the base of the core. Within Unit 7, reworking of 'older' moss layers is evident between c. 1500 and $1000 \mathrm{cal}$. yr BP. In the uppermost $50 \mathrm{~cm}$ of the core, the Bayesian age-depth model (Figure 2) favours the ${ }^{210} \mathrm{~Pb}$ data as being a more likely scenario, given the small errors associated with these ages and the age reversals present in radiocarbon data in the top $11 \mathrm{~cm}$ of the core. A more detailed assessment of the Fan Lake sedimentology, geochemistry and chronology, and an assessment of the impact of meltwater events on the lake system, will be presented in forthcoming papers.

\section{Palynology}

Pollen grains are well preserved through the core with influx continually high between approximately 350 and $150 \mathrm{~cm}$. The major taxa found throughout all the pollen zones are Acaena and Poaceae. Pollen of Asteraceae regularly occurs throughout the entire Fan Lake record.

Three major pollen zones (Fan1, Fan2 and Fan3a-e) were defined by the stratigraphically constrained cluster analysis. Fan1, Fan2 and Fan3d-e were statistically significant as assessed using the broken-stick analysis. Other zones defined by the stratigraphically constrained cluster analysis were not significant but retained to aid description and interpretation of the data (Figure 3).

\section{Pollen zone Fan I: 587-340 cm; 7700-3790 cal. yr BP}

Poaceae and Acaena are the dominant taxa in this zone with relative percentages of $80 \%$ and $10-20 \%$, respectively. A slight increase in Colobanthus (2-3\%) is found at 384 and $429 \mathrm{~cm}$. Nothofagus increases up to $3 \%$ at 500 and $515 \mathrm{~cm}$. Callitriche and Polypodium are found in small quantities $(<5 \%)$. Nothofagus slightly increases between 510 and $480 \mathrm{~cm}$ (Figure 3). The total pollen influx reaches 19,348 grains $\mathrm{cm}^{-2} \mathrm{yr}^{-1}$ at $384 \mathrm{~cm}$ (Figure 4).

\section{Pollen zone Fan2: 340-232 cm; 3790-3050 cal. yr BP}

A drop in Poaceae to $65-80 \%$ is recorded while Acaena increases to $10-35 \%$. Pollen grains derived from long-distance transport (e.g. Ephedra, Nothofagus, Podocarpaceae) are found in small quantities $(<1 \%)$. Colobanthus is consistently found at approximately $1 \%$ in this zone. Callitriche and Polypodium are the only other pollen taxa (1-2\%) consistently present (Figure 3). Higher pollen influx (5771-13,553 grains $\mathrm{cm}^{-2} \mathrm{yr}^{-1}$ ) is observed, along with higher Acaena (1493-3867 grains $\mathrm{cm}^{-2} \mathrm{yr}^{-1}$ ) and Callitriche (11-65 grains $\mathrm{cm}^{-2} \mathrm{yr}^{-1}$ ) (Figure 4).

\section{Pollen zone Fan3: 232-0 cm; 3050 cal. yr BP to present}

The pollen zone is characterised by lower Acaena (5-30\%) and higher Poaceae (70-90\%) pollen percentages. Callitriche, indeterminable and long-distance transport pollen grains, occur with slightly higher percentages $(0-3 \%)$ throughout this zone (Figure 3).
Pollen sub-zone Fan3a: 232-200 cm; 3050-2750 cal. yr BP

Increasing Acaena percentages (10-30\%) and decreasing Poaceae (70-90\%) percentages occur in this zone. Callitriche, Colobanthus and indeterminable grains stay between $0 \%$ and $1 \%$ (Figure 3). Total pollen influx peaks to 13,922 grains $\mathrm{cm}^{-2} \mathrm{yr}^{-1}$ in this zone with high Acaena (up to 4098 grains $\mathrm{cm}^{-2} \mathrm{yr}^{-1}$ ) and Callitriche (26-56 grains $\mathrm{cm}^{-2} \mathrm{yr}^{-1}$ ) (Figure 4).

\section{Pollen sub-zone Fan3b: 200-I54cm; 2750-2430 cal. yr BP}

Poaceae percentages remain from $70 \%$ to $80 \%$ through this zone, and Acaena declines to $17-20 \%$. At the top of this zone, a slight increase in Nassauvia (1-2\%) is found. Callitriche and Colobanthus remain around 2\% throughout the zone. Asteraceae (1\%) and a number of indeterminable undifferentiated grains increase. At $164 \mathrm{~cm}$, a large spike in the unknown sphere or ovoid is observed (Figure 3). Pollen influx begins to drop from 18,262 to 7910 grains $\mathrm{cm}^{-2} \mathrm{yr}^{-1}$ at the top of this zone. Callitriche increases to 85 grains $\mathrm{cm}^{-2} \mathrm{yr}^{-1}$ (Figure 4).

\section{Pollen sub-zone Fan3c: 154-94 cm; 2430-1670 cal. yr BP}

Poaceae percentages are on average higher compared with zone Fan3d, while Acaena percentages decrease. Colobanthus and Callitriche make up 1\% of the total pollen sum, while Polypodium makes up $<1 \%$. Ranunculus $(1 \%)$ first appears in this zone, while an increase in unknown monolete spores $(2 \%)$ is observed. At $140 \mathrm{~cm}$, a large increase in zygospores occurs, but overall, pollen influx continues to decline. Long-distance transport from South America is represented by pollen of Ephedra, Fabaceae, Nothofagus and Podocarpus. A peak in Nothofagus and Ephedra influx of 75 grains $\mathrm{cm}^{-2} \mathrm{yr}^{-1}$ is present at $131.5 \mathrm{~cm}$ (Figure 4). A high Callitriche influx of $3-75$ grains $\mathrm{cm}^{-2} \mathrm{yr}^{-1}$ is also observed.

\section{Pollen sub-zone Fan3d: 94-33 cm; 1670-430 cal. yr BP}

Poaceae decreases to $70-90 \%$ of the pollen sum, whereas Acaena increases from $10-30 \%$. At $92 \mathrm{~cm}$, a slight increase $(3 \%)$ is found in Callitriche, Polypodium, indeterminable and fungal undifferentiated spores. Callitriche is consistently higher in this zone (1-2\%) compared with the rest of the core. Colobanthus and Polypodium taxa are found in small percentages $(<5 \%)$. Blechnum $(<1 \%)$ is present for the first time in this zone. An increase in pollen influx up to 10,011 grains $\mathrm{cm}^{-2} \mathrm{yr}^{-1}$ is observed at $60 \mathrm{~cm}$.

\section{Pollen sub-zone Fan3e: $33-0 \mathrm{~cm} ; 430 \mathrm{cal}$. yr BP to recent}

Poaceae percentages increase and Acaena percentage decreases in this zone. Monolete and trilete spores, indeterminable grains and fungal spores undifferentiated increase to $2 \%$. Callitriche and Colobanthus remain around 1-2\%. Ranunculus and Polypodium comprise $<1 \%$ of the pollen sum. Sphagnum $(<1 \%)$ is found in this zone for the first time. Nothofagus increases to $>1 \%$ between $20 \mathrm{~cm}$ and $17 \mathrm{~cm}$ (Figure 3 ).

\section{PCA}

PCA was used to investigate statistical relationships within the pollen dataset, which could help to identify floral assemblages composed of co-occurring taxa with similar environmental preferences. The first and second PCA axes explain 34\% of the total 


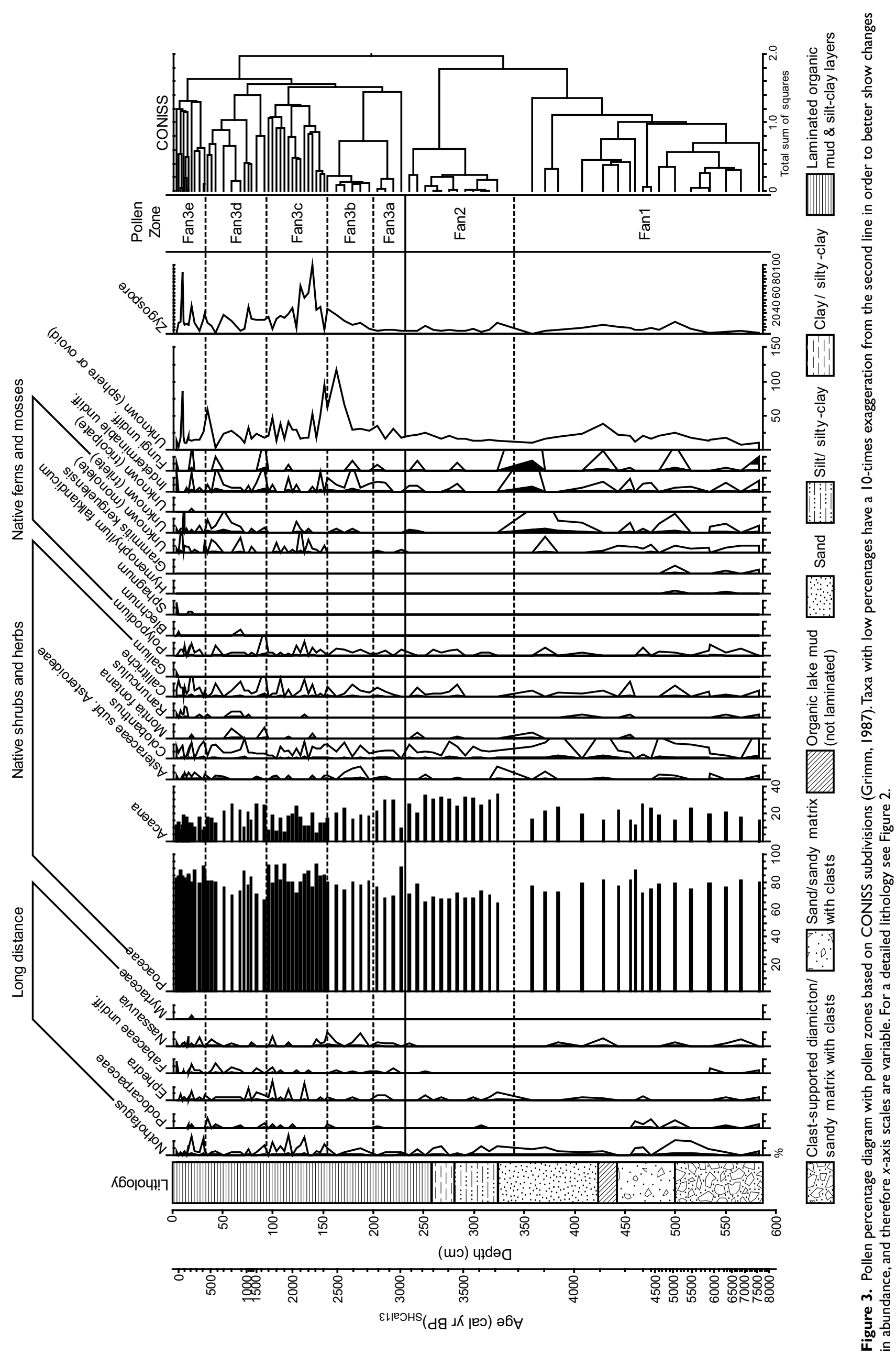




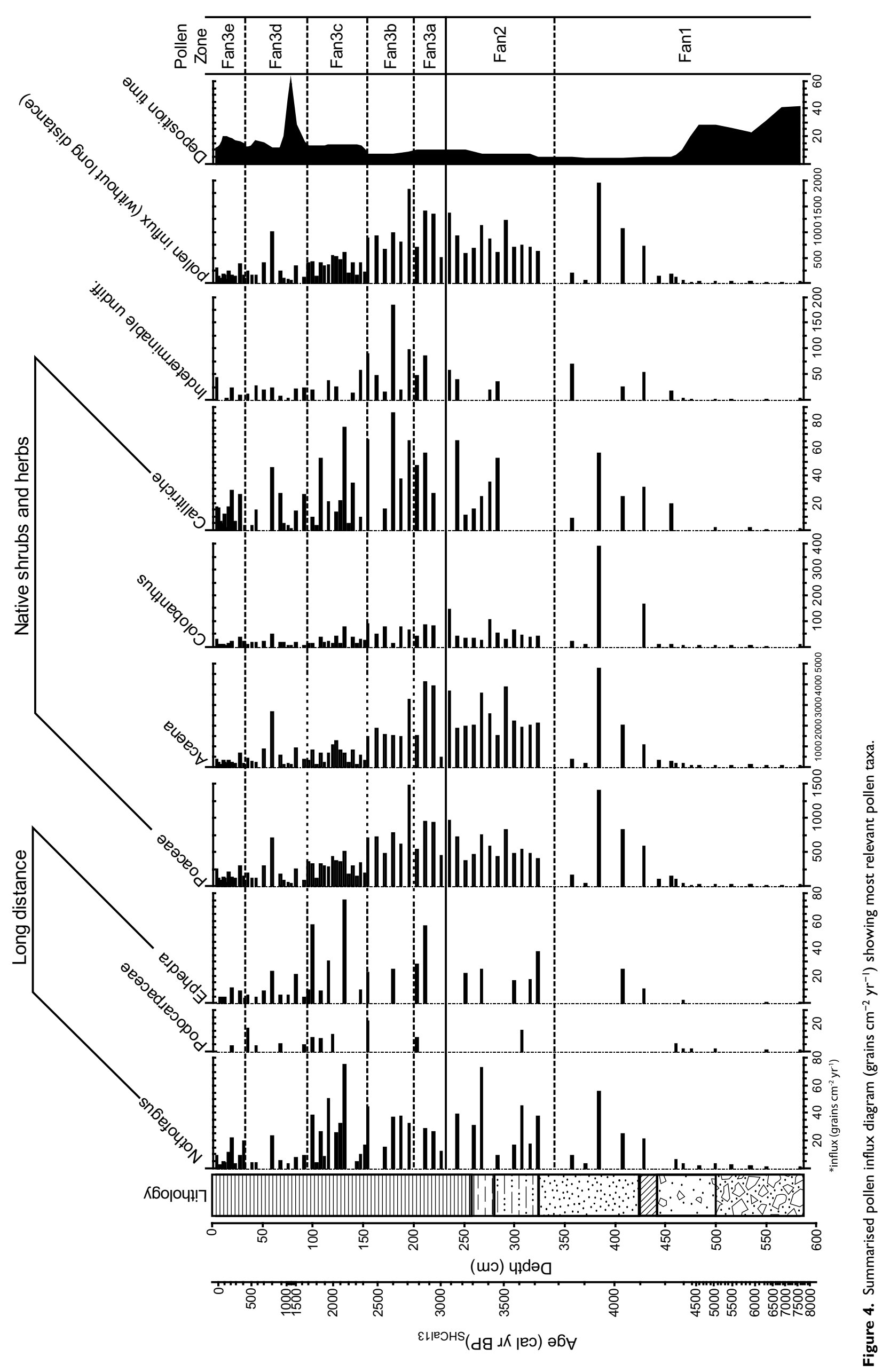




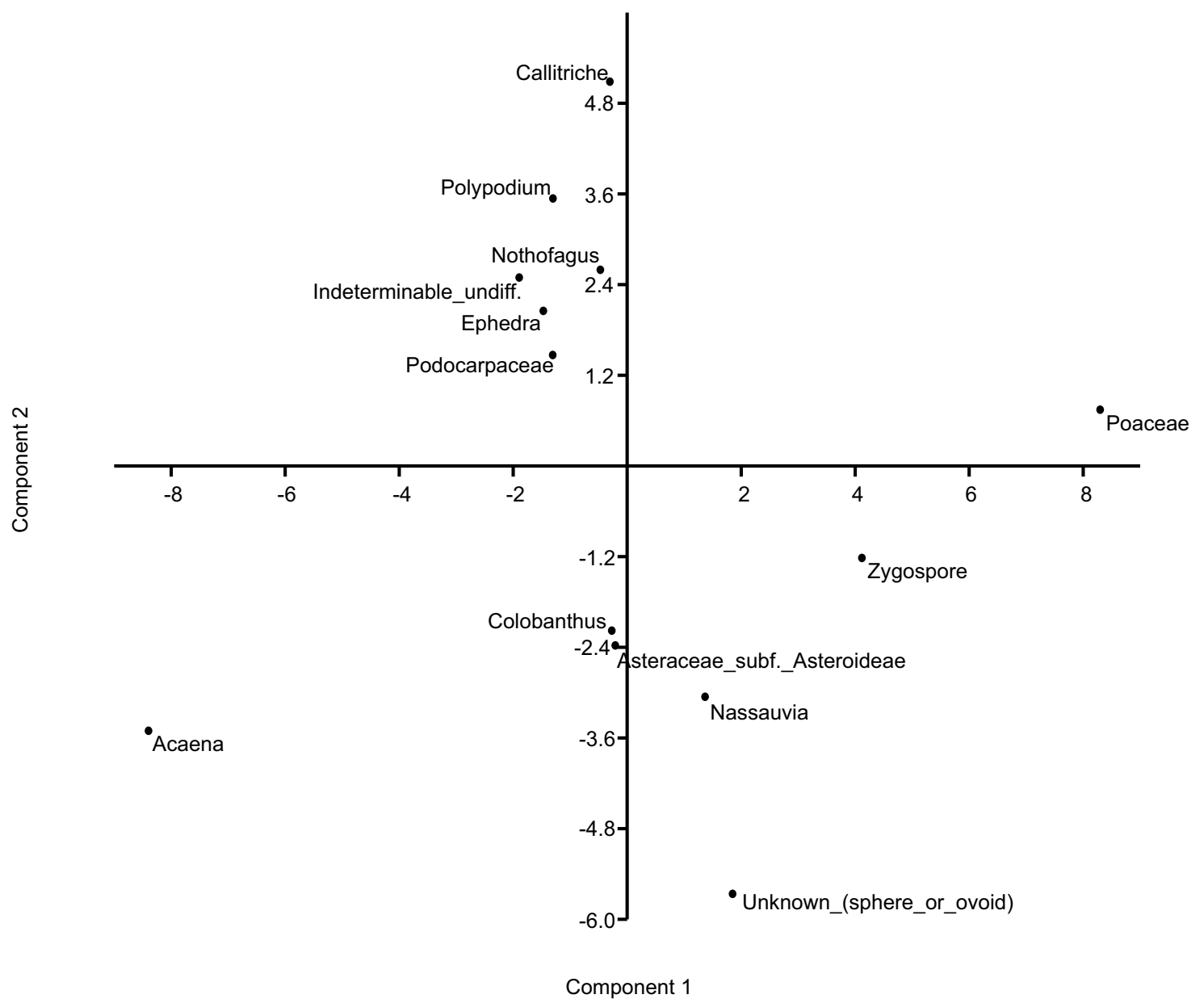

Figure 5. PCA of the Fan Lake pollen data showing the scores for the main pollen types (Acaena,Asteraceae, Callitriche, Colobanthus, Ephedra, indeterminable, Nassauvia, Nothofagus, Podocarpaceae, Poaceae, Polypodium, unknown cyst and Zygospore) on the first two principal components. Based on the ecological preferences of these taxa the first axis is interpreted as being related to temperature and the second to precipitation. PCA: principal components analysis.

variation. The first PCA axis explains $20 \%$ of the variance and clearly separates the dominant taxa Acaena and Poaceae, providing evidence that they are indicators of different environmental conditions (Figure 5). Although the climate of South Georgia has more than likely remained 'cold' and 'wet' throughout the Holocene, the first PCA axis likely represents a subtle shift in the climate gradient from relatively 'warmer' to 'cooler' conditions, with the second PCA axis indicating a shift along a 'drier' to 'wetter' gradient. The PCA separates the aquatic taxa Callitriche on the second PCA axis from the indeterminable (eroded) pollen grains, possibly indicative of 'wetter' environments, and longdistance taxa (Ephedra, Nothofagus, Podocarpaceae), which are likely related to increasing wind transport. These interpretations are further confirmed by negative sample score values of the first and second PCA axes (Figure 6), indicating slightly warmer and drier environments, and positive sample scores possibly representing cooler and wetter conditions.

\section{Confidence intervals of long-distance taxa}

The $95 \%$ confidence intervals were plotted for the long-distance taxa (Figure 6) to identify significant changes in longdistance pollen transport (a function of SHW strength) and to separate them from random variations inherent in the percentage counts (Maher, 1972). Confidence limits overlap throughout the majority of the Fan Lake record indicating few significant changes in long-distance pollen transport. However, pollen influx of long-distance taxa such as Nothofagus and Ephedra is highest in zone Fan3c (Figure 4), and the highest percentage peaks with non-overlapping confidence intervals occur at $99.5 \mathrm{~cm}$ (c. $1745 \mathrm{cal}$. yr BP) and $20 \mathrm{~cm}$ (c. $226 \mathrm{cal}$. yr BP) during periods of potentially colder and wetter climate.

\section{Discussion}

\section{Challenges in the interpretation of sub-Antarctic pollen records}

Despite the treeless and phanerogam-poor sub-Antarctic vegetation (Van der Putten et al., 2012b) and the low pollen diversity, the Fan Lake record shows interpretable changes in the major pollen taxa (i.e. Acaena and Poaceae) and the occurrence of environmental indicator taxa (e.g. Callitriche, indeterminable) that can be used, along with sedimentological evidence, to constrain mid- to late Holocene climate changes.

Changes in the relative abundance of pollen from $C$. antarctica can be used as indicators of wetter climatic conditions (Barrow, 1983). Long-distance pollen grain influx from the South American continent also provides evidence for increased pollen transport by the SHW (Schalke and Van Zinderen Bakker, 1971). The reliable identification of warmer and colder climate periods in the Fan Lake record remains challenging, and the alternating dominance of Acaena and Poaceae is difficult to interpret. Within the genus, A. magellanica is currently the dominant taxon on South Georgia and prefers lowland environments on moist peat or dry scree, while $A$. tenera inhabits high altitude areas (Walton, 1976). The two species could not be differentiated in the pollen records. However, it is most likely that at Fan Lake, the pollen 


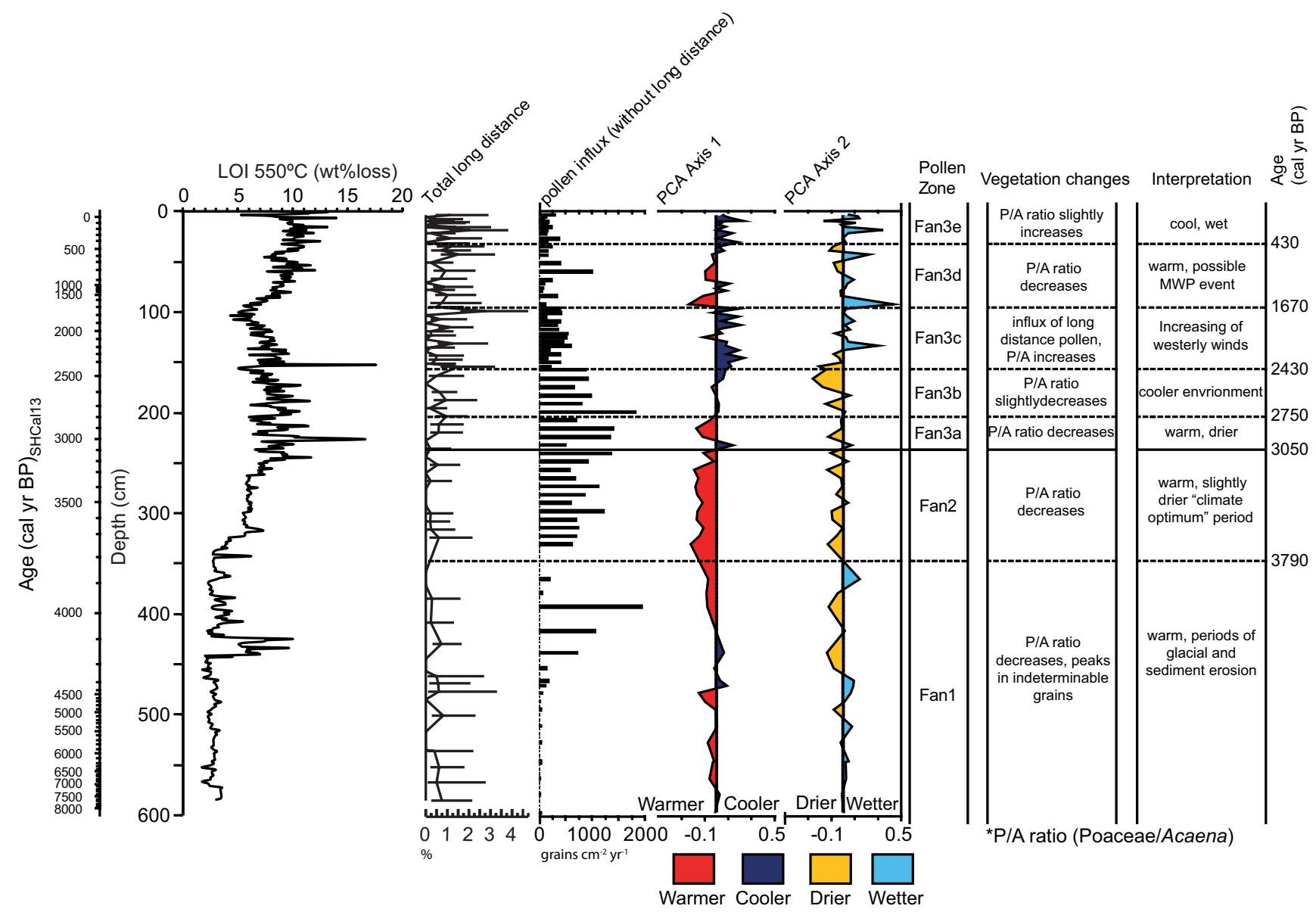

Figure 6. Overview figure showing loss-on-ignition (LOI 550 ${ }^{\circ} \mathrm{C}$ ) (wt\% loss), total long-distance taxa: Ephedra, Fabaceae undiff., Myrtaceae, Nassauvia, Nothofagus and Podocarpaceae plotted with $95 \%$ confidence interval, total pollen influx showing the most relevant pollen taxa, sample scores for the first and second principal components of the PCA and general vegetation and climate changes observed in the Fan Lake core throughout the Holocene.

PCA: principal components analysis.

was produced by the more abundant species A. magellanica that populated the peat around the lake during the Holocene.

The Fan Lake record shows a significant change at c. 2750 cal. yr BP from an Acaena- to a more Poaceae-dominated pollen assemblage. The timing of this change is broadly coincident with late Holocene cooling events identified by many other palaeoenvironmental studies from the sub-Antarctic islands (Table 1; e.g. Bentley et al., 2009; Unkel et al., 2010). Barrow and Lewis Smith (1983) also concluded from a pollen record from Sphagnum Valley, South Georgia, that high Acaena pollen percentages may indicate warmer or drier, and high Poaceae percentages cooler or cool-wetter climates. High Acaena percentages in Holocene pollen records have also been used on the Kerguelen Islands and Marion Island to identify warmer and drier climates, respectively (Scott and Hall, 1983; Young and Schofield, 1973). Despite these previous studies, we still treat the interpretation of Acaena and Poaceae with caution because in the South Indian Ocean sector, Van der Putten et al. (2010) could not demonstrate a relationship between the occurrence of $A$. magellanica and warmer climates. We therefore consider other proxies such as organic carbon and sedimentological evidence in addition to Acaena and Poaceae to support our palaeoclimate interpretations.

\section{Local lake environments}

During the mid-Holocene, Fan Lake was surrounded by subAntarctic vegetation mainly consisting of small shrubs and herbs, such as Acaena, Asteraceae, Callitriche and Colobanthus. The presence of Asteraceae is in agreement with findings from Lake Maiviken, South Georgia (Birnie, 1990). Osborne et al. (2009) considered this family as introduced, but we agree with Birnie (1990) in that Asteraceae might be native to South Georgia. The lithology between $\sim 7700$ and 3790 cal. yr BP is characterised by poorly sorted sediment such as clast-supported diamicton, a sandy matrix with clasts and sand along with the presence of indeterminable, eroded pollen grains which point to fast flowing waters, erosion and persistent glacial activity in the mid-upper catchment. Increasing temperatures at the beginning of the Holocene probably caused local glacier retreat and increased meltwater input into Fan Lake. Minor and fluctuating increases of Colobanthus between 7590 and 3950 cal. yr BP might indicate short drier periods with reduced precipitation or reduced periods of meltwater input, as this small sub-Antarctic shrub today inhabits drier environments (Convey et al., 1999).

A peak in indeterminable grains, fern and fungal spores at $\sim 3860$ cal. yr BP suggests a relatively short disturbance and soil erosion, which coincides with an influx of coarse sand and some of the highest sedimentation rates $(0.2-0.4 \mathrm{~cm} / \mathrm{yr})$ in the core (Figure 2). The subsequent decrease in the percentage of indeterminable grains at $\sim 3790$ cal. yr BP could indicate a slow progression towards a less glaciated mid-upper catchment and may coincide with the onset of a late Holocene 'climate optimum'. A strong increase in pollen influx and organic carbon suggests higher catchment biomass within lake production between $\sim 3230$ and 2710 cal. yr BP. A warmer-than-present environment is inferred from an increase in Acaena around Fan Lake, probably predominantly residing in the lower altitude moist peat areas. 
From c. 2750 cal. yr BP (Pollen sub-zone Fan3b), several changes in the Fan Lake pollen and sediment record indicate the progression towards a cooler and wetter environment in the late Holocene. A sharp drop in total pollen influx suggests decreasing plant biomass. The contemporaneous slight increase in sediment grain size in pollen zone Fan3b along with an increase in indeterminable and eroded pollen grains suggest higher sediment and water inputs possibly from seasonal melting of snowfields in the catchment. Coinciding with this drop in total pollen influx is an increase in Callitriche, suggesting a generally wetter environment from 2750 cal. yr BP onwards. The water-starwort Callitriche, which today colonises moist habitats on South Georgia (Convey et al., 1999), possibly grew in the lower catchment areas of the Holocene Fan Lake where water may have collected in the bogs. The regular flooding might have also caused a general decline in Acaena, which formerly occupied these habitats. Further evidence suggesting a changing lake environment includes the increase in percentages of unknown spheres or ovoids, and the zygospores, which peak at $\sim 2495$ and $\sim 2260$ cal. yr BP, respectively. The origin of both palynomorphs is unknown. However, it is likely that they have been produced within the lake (e.g. by algae), possibly indicating a rapid change in lake ecology.

Two colder/wetter periods can be identified between $c$. 27501670 and c. 710 cal. yr BP to present if we assume that AcaenaPoaceae ratio can be applied to reconstruct temperature and/or precipitation changes (see discussion above). Although a slight trend towards an increase in organic content is observed from $c$. 710 cal. yr BP to present, a greater influx of Callitriche and a low total pollen influx suggest cooler and wetter conditions towards the present. The interpretation of warmer/drier environmental conditions between $c$. 1670-710 cal. yr BP is supported by higher Acaena pollen percentages and a contemporaneous increase in pollen influx and organic content (Figures 3 and 6).

\section{Long-distance signal}

Long-distance pollen grains from the South American continent are regularly present in the Fan Lake record. Changes in the abundance of the long-distance grains can aid in determining latitudinal shifts or changes in the intensity of the SHW (Bentley et al., 2009; Markgraf et al., 2003; Moreno et al., 2009). The long-distance signal is dominated by pollen from the southern beech Nothofagus, the conifer Podocarpus and the shrub Ephedra. Nothofagus and Podocarpus are today abundant forest trees in temperate and warm temperate climate zones of South America (Veblen et al., 1995, 1996) but also colonise as shrubs, together with Nassauvia and Ephedra, the sub-Antarctic vegetation of southern South America, for example, southern Patagonia and Tierra del Fuego (Björck et al., 2012; Markgraf et al., 2007; Montade et al., 2012). Because of the wide climate tolerance of these taxa, Holocene climate variability and a subsequent shift of vegetation zones in southern South America are unlikely to have a major impact on the total influx of long-distance pollen grains on South Georgia.

The Fan Lake record shows slight increases in long-distance pollen influx throughout the late Holocene cooling after 2430 cal. yr BP. Small peaks are present between approximately 2210 and 1670 cal. yr BP (Figure 4). The highest abundance of long-distance pollen occurs during the inferred cooler and wetter periods on Annenkov Island. Ephedra and Nothofagus comprise the majority of the long-distance signal, suggesting that the pollen grains have been transported from the southernmost, sub-Antarctic vegetation of South America (rather than from the Podocarpus- and Nothofagus-rich cool temperate rainforests).

\section{Climate change}

The Fan Lake record provides evidence of warmer conditions in the mid- to late Holocene, which culminates in a period of comparatively higher biomass production between 3790 and 2750 cal. yr BP. With a subsequent gradual change towards slightly cooler and wetter environments after c. 2750 cal. yr BP, the pollen-based climate reconstruction from the Fan Lake record broadly agrees with other South Georgia, Antarctic Peninsula, maritime- and sub-Antarctic records (see Table 1; e.g. Bentley et al., 2009; Unkel et al., 2010).

Previous records from the north coast of South Georgia suggest several cooling and drying events during the mid- to late Holocene, but no strong signal of these changes are present on Annenkov Island. For example, from grey scale density, weightloss-on-ignition and grain size analyses, Rosqvist and Schuber (2003) reconstructed cooler periods between 7800 and 7400 cal. yr BP, 7200 and 7000 cal. yr BP, 5200 and 4400 cal. yr BP and 2400 and 1600 cal. yr BP. The slight increases in the pollen percentages of the cushion plant Colobanthus might indicate short dry events around 7590-3950 cal. yr BP, which roughly coincide with dry periods previously identified by Van der Putten et al. (2004, 2009) through macrofossil analyses at Tønsberg Point (8800-8200 cal. yr BP) and Kanin Point (4400-3400 cal. yr BP) on the north coast of South Georgia.

Rosqvist and Schuber (2003) indicate cooling on South Georgia between 2400 and 1600 cal. yr BP based on glacial advances, although the accuracy of these dates have been questioned (Moreton et al., 2004). The interpretation of a late Holocene climate change at Fan Lake is also supported by lake sediment studies on South Georgia (Lake Maiviken), which suggest the onset of wetter conditions at c. $2750 \mathrm{cal}$. yr BP (Birnie, 1990). However, recent macrofossil studies from Kanin Point and Tønsberg are more contradictory (Van der Putten et al., 2009). While Tønsberg assemblages suggest a change from wet to extremely wet conditions at $2200 \mathrm{cal}$. yr BP, Kanin Point seems to have developed from a wet to a dry peat bank environment (Van der Putten et al., 2009). Since the Tønsberg sequence was located in a depression, it was more likely affected by higher precipitation. In contrast, the Kanin Point vegetation responded to a decrease in temperature allowing a Warnstorfia bog to be introduced by Chorisodontium aciphyllum and Polytrichum cf. strictum, indicating wetter environments (Van der Putten et al., 2009). Various lake sediments, pollen and macrofossil proxy data also suggest a cooler period on South Georgia that started at c. 2200 cal. yr BP (Clapperton et al., 1989; Van der Putten et al., 2009, 2012a).

Various sub- and maritime-Antarctic islands and Antarctic Peninsula records closely resemble Fan Lake in showing a late Holocene 'climate optimum', late Holocene cooling and a possible warming overlapping with the 'Medieval Climate Anomaly' ('MCA') (Table 1). At Fan Lake, the warm and stable lake conditions inferred between 3790 and 2750 cal. yr BP overlap with the late Holocene 'climate optimum' from c. 3500 to 1150 cal. yr BP on maritime-Antarctic Signy Island, at $850 \mathrm{~km}$ distance (Hodgson and Convey, 2005; Jones et al., 2000). Similar to Fan Lake, multiple lake sediment records from Signy Island suggest a late Holocene 'climate optimum' through LOI and pollen concentration data. This interpretation also coincides with the late Holocene Hypsithermal in the Beak 1 Lake record between 3169 and 2120 cal. yr BP from Beak Island in the Prince Gustav Channel, NE Antarctic Peninsula, as indicated by an increase in sediment accumulation and a peak in organic carbon, along with increased primary production (Sterken et al., 2012). Other examples of a climate optimum starting at around the mid-late Holocene boundary (4200 yr BP), or in the first part of the late Holocene, are described by Bentley et al. (2009) and Hodgson et al. (2009).

From 2710 cal. yr BP onwards, the decline in pollen influx in the Fan Lake record indicates a change towards a generally cooler and wetter climate, which persisted until today. With several interbedded warm and cold periods, the climate on Annenkov Island has been very variable throughout the last 2700 years. The majority of research in the sub-Antarctic puts the start of cooling in the 
late Holocene at c. 2500 cal. yr BP, but uncertainty still remains as to the exact timing (Bentley et al., 2009; see also Table 1).

At the end of the late Holocene, increased Acaena pollen percentages, high pollen influx and increased organic flux suggest the existence of a relatively warmer period at Fan Lake which was centred around 1670-710 cal. yr BP. The signature of this extended period of late Holocene warming has been detected at several Antarctic Peninsula (e.g. Bentley et al., 2009) and South American locations (e.g. Kastner et al., 2010; Mauquoy et al., 2004; Neukom et al., 2010) and overlaps with the timing of both the earlier Northern and later Southern Hemisphere expression of a 'MCA' (Neukom et al., 2014). The effects of the 'MCA' have been reported in both hemispheres, but the timing of these events varies widely (Bird et al., 2011; Ledru et al., 2013; Neukom et al., 2010). This led Neukom et al. (2014) to conclude that there is no empirical support for a globally coherent warm phase during the pre-industrial (AD 1000-1850) era.

\section{SHW and climate changes}

The influx of non-native long-distance transported pollen grains in fossil records from the sub-Antarctic islands is primarily controlled by wind strength and the latitudinal position of the SHW and is therefore indicative of changes in atmospheric circulation patterns (e.g. Van der Putten et al., 2012b). Climate models and observational data suggest that during cold periods, the SHW shifts towards the equator, whereas during warmer phases (such as today), the movement is polewards (Bentley et al., 2009; Lamy et al., 2001; Toggweiler et al., 2006; Varma et al., 2012). However, how latitudinal shifts of wind belts affected precipitation and wind strength in the sub-Antarctic region (at c. 50 5 ) and whether these wind belts contracted or expanded throughout the Holocene remains debated (Hodgson and Sime, 2010).

Multi-proxy studies on lake sediment cores in SW Patagonia and Chile show increased wind strength along with increases in precipitation during cooler periods in the late Holocene, such as the 'Little Ice Age' ('LIA'), 400-150 cal. yr BP (Bentley et al., 2009; Moy et al., 2008). Increased wind strength and precipitation associated with the SHW could have caused the expansion of Nothofagus-dominated woodlands in SW Patagonia and Tierra del Fuego in the late Holocene (Moreno et al., 2009; Moy et al., 2011). However, during the mid-Holocene, Lamy et al. (2001) suggested poleward westerly wind shifts occurred in phase with warmer temperatures, changing to an anti-phased relationship in the late Holocene. As a result of this anti-phasing between the core and the northern margin, the core SHW belt became stronger during the early Holocene and weaker during the late Holocene (Lamy et al., 2010).

In contrast, the pollen record from Fan Lake situated at c. $54^{\circ} \mathrm{S}$ provides evidence of a strengthening of the SHW during the late Holocene. Although the overall number of grains per sample and the percentage variations are relatively low, the Fan Lake record suggests that highest transport by westerly winds occurred during late Holocene cold periods at 2210-1670 cal. yr BP and after 710 cal. yr BP.

\section{Conclusion}

Most existing palaeoenvironmental records from the Antarctic and sub-Antarctic islands broadly identify a trend from a warm period in the beginning of the late Holocene followed by a prolonged cooling phase, but several uncertainties remain in defining the timing and underlying drivers for these past changes.

The well-dated, $5.8 \mathrm{~m}$-long sediment record from Fan Lake on Annenkov Island, near South Georgia, was used to reconstruct the Holocene vegetation and climate history of the South Atlantic sector of the Southern Ocean at a high temporal resolution. We identified three key phases in the pollen record from Fan Lake: (1) a warm late Holocene 'climate optimum' from c. 3790 to 2750 cal. yr BP, with stable, but low, in-lake productivity and high biomass production; (2) a step-change after 2750 cal. yr BP toward cooler and wetter environmental conditions, as indicated by a decline in Acaena pollen, a rise of the aquatic plant Callitriche and an increase in indeterminable, eroded pollen grains; (3) a return to slightly warmer conditions between 1670 and $710 \mathrm{cal}$. yr BP, overlapping with some warm events associated with a 'MCA' in the Northern and Southern Hemispheres.

The presence of long-distance transport pollen grains in the Fan Lake record was used to reconstruct changes in atmospheric circulation patterns. Although the overall number of long-distance transport pollen grains in the Fan Lake record was comparatively low, the pollen record suggests a link between cold periods and stronger SHW in the late Holocene at this location.

Further studies are needed to better understand the history of the SHW and their impact on Holocene climate change. We suggest that future research should focus on coring sites on the west coasts of sub-Antarctic islands, close enough to the continental landmasses to show a distinct signal of long-distance pollen grain transport.

\section{Acknowledgements}

E. Verleyen was a postdoctoral research fellow of the Fund for Scientific Research Flanders, Belgium. Andy Lole is thanked for his assistance in the field and the captain and crew of the HMS Endurance and 815 Naval Air Squadron for logistic support. Sally Poncet is thanked for providing an initial reconnaissance of Fan Lake and helping to plan helicopter access routes avoiding nesting birds. The Government of South Georgia and the South Sandwich Islands is acknowledged for granting a permit to work in the Annenkov Island Site of Special Scientific Interest. Figure 1 contains public sector information, licensed under the Open Government Licence v2.0, from UKHO (https://www.nationalarchives.gov.uk/ doc/open-government-licence/version/2/). We thank the two anonymous reviewers for their constructive comments and suggestions.

\section{Funding}

This study was funded by the UK Natural Environment Research Council through the British Antarctic Survey Quaternary Sediments Work Package and NERC grant NEB K00414 1 (led by D. A. Hodgson) and the Belgian Science Policy Office project HOLANT (led by W. Vyverman).

\section{References}

Anderson RF, Ali S, Bradtmiller LI et al. (2009) Wind-driven upwelling in the Southern Ocean and the deglacial rise in atmospheric $\mathrm{CO}_{2}$. Science 323: 1443-1448.

Appleby PG (2001) Chronostratigraphic techniques in recent sediments. In: Last WM and Smol JP (eds) Tracking Environmental Change Using Lake Sediments. Dordrecht: Springer, pp. 171-203.

Appleby PG and Oldfield F (1978) The calculation of lead-210 dates assuming a constant rate of supply of unsupported ${ }^{210} \mathrm{~Pb}$ to the sediment. Catena 5: 1-8.

Barrow CJ (1976) Palynological studies in South Georgia: I. Pollen and spore morphology of the native vascular species. British Antarctic Survey Bulletin 43: 63-75.

Barrow CJ (1978) Postglacial pollen diagrams from South Georgia (sub-Antarctic) and West Falkland Island (South Atlantic). Journal of Biogeography 5(3): 251-274.

Barrow CJ (1983) Palynological studies in South Georgia: IV. Profiles from Barff Peninsula and Annenkov Island. British Antarctic Survey Bulletin 58: 61-70.

Barrow CJ and Lewis Smith RI (1983) Palynological studies in South Georgia. II. Two profiles in Sphagnum Valley, Cumberland West Bay. British Antarctic Survey Bulletin 58: 15-42. 
Bennett K (2008) Psimpoll and Pscomb. Available at: http:// chrono.qub.ac.uk.

Bentley MJ, Evans DJA, Fogwill CJ et al. (2007) Glacial geomorphology and chronology of deglaciation, South Georgia, sub-Antarctic. Quaternary Science Reviews 26: 644-677.

Bentley MJ, Hodgson DA, Smith JA et al. (2009) Mechanisms of Holocene palaeoenvironmental change in the Antarctic Peninsula region. The Holocene 19: 51-69.

Bird BW, Abbott MB, Vuille M et al. (2011) A 2,300-yearlong annually resolved record of the South American summer monsoon from the Peruvian Andes. Proceedings of the National Academy of Sciences of the United States of America 108: 8583-8588.

Birnie J (1990) Holocene environmental change in South Georgia: Evidence from lake sediments. Journal of Quaternary Science 5(3): 171-187.

Björck S, Håkansson, H, Olsson S et al. (1993) Palaeoclimatic studies in South Shetland Islands, Antarctica, based on numerous stratigraphic variables in lake sediments. Journal of Paleolimnology 8: 233-272.

Björck S, Håkansson, H, Zale R et al. (1991) A late Holocene lake sediment sequence from Livingston Island, South Shetland Islands, with palaeoclimatic implications. Antarctic Science 3(1): 61-72.

Björck S, Olsson S, Ellis-Evans C et al. (1996) Late Holocene palaeoclimatic records from lake sediments on James Ross Island, Antarctica. Palaeogeography, Palaeoclimatology, Palaeoecology 121: 195-220.

Björck S, Rundgren M, Ljung K et al. (2012) Multi-proxy analyses of a peat bog on Isla de los Estados, easternmost Tierra del Fuego: A unique record of the variable Southern Hemisphere Westerlies since the last deglaciation. Quaternary Science Reviews 42: 1-14.

Blaauw M and Christen JA (2011) Flexible paleoclimate agedepth models using an autoregressive gamma process. Bayesian Analysis 6(3): 457-474.

Bronk Ramsey C (2009) Bayesian analysis of radiocarbon dates. Radiocarbon 51(1): 337-360.

Clapperton CM, Sugden DE, Birnie J et al. (1989) Late-glacial and Holocene glacier fluctuations and environmental change on South Georgia, Southern Ocean. Quaternary Research 31: 210-228.

Clark KR and Gorley RN (2006) PRIMER v6: User Manual/Tutorial. Plymouth: PRIMER-E Ltd.

Convey P, Greenslade P, Arnold RJ et al. (1999) Collembola of sub-Antarctic South Georgia. Polar Biology 22: 1-6.

Dean WE (1974) Determination of carbonate and organic-matter in calcareous sediments and sedimentary-rocks by loss on ignition - Comparison with other methods. Journal of Sedimentary Petrology 44: 242-248.

Fægri K and Iversen I (1989) Textbook of Pollen Analysis (ed K Fægri, PE Kaland and K Krzywinski). 4th Edition. Chichester: John Wiley \& Sons.

Fletcher MS and Moreno PI (2012) Have the Southern Westerlies changed in a zonally symmetric manner over the last 14,000 years? A hemisphere-wide take on a controversial problem. Quaternary International 253: 32-46.

Fretwell P, Convey P, Fleming A et al. (2011) Detecting and mapping vegetation distribution on the Antarctic Peninsula from remote sensing data. Polar Biology 34: 273-281.

Greene SW (1969) New records for South Georgian vascular plants. British Antarctic Survey Bulletin 22: 49-59.

Greene SW and Walton DWH (1975) An annotated checklist of the sub-Antarctic and Antarctic vascular flora. Polar Record 17(110): 473-484.

Grimm EC (1987) CONISS: A FORTRAN 77 program for stratigraphically constrained cluster analysis by the method of incremental sum of squares. Computers \& Geosciences 13: $13-35$.

Grimm EC (1990) TILIA and TILIA. GRAPH: PC spreadsheet and graphics software for pollen data (Version 2.0.b.4). INQUA - Commission for the Study of the Holocene, Working-Group on Data-Handling Methods. Newsletter 4: 5-7.

Gunn DE and Best AI (1998) A new automated nondestructive system for high resolution multi sensor core logging of open sediment cores. Geo-Marine Letters 18: 70-77.

Hammer $\varnothing$, Harper DAT and Ryan PD (2001) PAST: Paleontological statistics software package for education and data analysis. Palaeontologia Electronica 4: 1-9.

Hodgson DA and Convey P (2005) A 7000-year record of oribatid mite communities on a Maritime-Antarctic Island: Responses to climate change. Arctic, Antarctic, and Alpine Research 37(2): 239-245.

Hodgson DA and Sime LC (2010) Palaeoclimate: Southern westerlies and $\mathrm{CO}_{2}$. Nature Geoscience 3: 666-667.

Hodgson DA, Abram N, Anderson J et al. (2009) Antarctic climate and environment history in the pre-instrumental period. In: Turner J, Convey P, Di Prisco G et al. (eds) Antarctic Climate Change and the Environment. Cambridge: Scientific Committee for Antarctic Research, pp. 115-182.

Hogg AG, Hua Q, Blackwell PG et al. (2013) SHCal13 Southern Hemisphere calibration, 0-50,000 years cal. BP. Radiocarbon 55(2): 1-15.

Hua Q, Barbetti M and Rakowski AZ (2013) Atmospheric radiocarbon for the period 1950-2010. Radiocarbon 55(4): 20592072.

Jones VJ, Hodgson DA and Chepstow-Lusty A (2000) Palaeolimnological evidence for marked Holocene environmental changes on Signy Island, Antarctica. The Holocene 10(1): 43-60.

Juggins S (2012) rioja: Analysis of Quaternary Science DataVersion 0.7-3 (Program). CRAN. Available at: http://cran.rproject.org/package=rioja (accessed April 2014).

Kastner S, Enters D, Ohlendorf C et al. (2010) Reconstructing 2000 years of hydrological variation derived from laminated proglacial sediments of Lago del Desierto at the eastern margin of the South Patagonian Ice Field, Argentina. Global and Planetary Change 72: 201-214.

Lamy F, Hebbeln D, Rohl U et al. (2001) Holocene rainfall variability in southern Chile: A marine record of latitudinal shifts of the Southern Westerlies. Earth and Planetary Science Letters 185: 369-382.

Lamy F, Kilian R, Arz HW et al. (2010) Holocene changes in the position and intensity of the southern westerly wind belt. Nature Geoscience 3: 695-699.

Ledru MP, Jomelli V, Samaniego P et al. (2013) The Medieval Climate Anomaly and the Little Ice Age in the eastern Ecuadorian Andes. Climate of the Past 9: 307-321.

Le Quéré C, Rödenbeck C, Buitenhuis ET et al. (2010) Impact of climate change and variability on the global oceanic sink of $\mathrm{CO}_{2}$. Global Biogeochemical Cycles 24: 1-10.

Maher LJ (1972) Nomograms for computing 0.95 confidence limits of pollen data. Review of Palaeobotany and Palynology 13: 85-93.

Markgraf V and D'Antoni HL (1978) Pollen Flora of Argentina: Modern Spore and Pollen Types of Pteridophyta, Gymnospermae, and Angiospermae. Tucson, AZ: University of Arizona Press.

Markgraf V, Whitlock C and Haberle S (2007) Vegetation and fire history during the last 18,000 cal. yr B.P. in Southern Patagonia: Mallín Pollux, Coyhaique, Province Aisén $\left(45^{\circ} 41^{\prime} 30^{\prime \prime} \mathrm{S}\right.$, $71^{\circ} 50^{\prime} 30^{\prime \prime} \mathrm{W}, 640 \mathrm{~m}$ elevation). Palaeogeography, Palaeoclimatology, Palaeoecology 254: 492-507.

Markgraf V, Bradbury JP, Schwalb A et al. (2003) Holocene palaeoclimates of southern Patagonia: Limnological and 
environmental history of Lago Cardiel, Argentina. The Holocene 13(3): 597-607.

Masson V, Vimeux F, Jouzel J et al. (2000) Holocene climate variability in Antarctica based on 11 ice-core isotopic records. Quaternary Research 54(3): 348-358.

Mauquoy D, Blaauw M, Geel van B et al. (2004) Late Holocene climatic changes in Tierra del Fuego based on multiproxy analyses of peat deposits. Quaternary Research 61: $148-158$

Michalchuk BR, Anderson JB, Wellner JS et al. (2009) Holocene climate and glacial history of the northeastern Antarctic Peninsula: the marine sedimentary record from a long SHALDRIL core. Quaternary Science Reviews 28: 3049-3065.

Montade V, Nebout NC, Chapron E et al. (2012) Regional vegetation and climate changes during the last $13 \mathrm{kyr}$ from a marine pollen record in Seno Reloncavi, southern Chile. Review of Palaeobotany and Palynology 181: 11-21.

Moreno PI, François JP, Moy CM et al. (2010) Covariability of the Southern Westerlies and atmospheric $\mathrm{CO}_{2}$ during the Holocene. Geology 38(8): 727-730.

Moreno PI, François JP, Villa-Martínez RP et al. (2009) Millennial-scale variability in Southern Hemisphere westerly wind activity over the last 5000 years in SW Patagonia. Quaternary Science Reviews 28: 25-38.

Moreton SG, Rosqvist GC, Davies SJ et al. (2004) Radiocarbon reservoir ages from freshwater lakes, South Georgia, subAntarctic: Modern analogues from particulate organic matter and surface sediments. Radiocarbon 46(2): 621-626.

Moy CM, Dunbar RB, Guilderson TP et al. (2011) A geochemical and sedimentary record of high southern latitude Holocene climate evolution from Lago Fagnano, Tierra del Fuego. Earth and Planetary Science Letters 302: 1-13.

Moy CM, Dunbar RB, Moreno PI et al. (2008) Isotopic evidence for hydrologic change related to the westerlies in SW Patagonia, Chile, during the last millennium. Quaternary Science Reviews 27(13): 1335-1349.

Neukom R, Gergis J, Karoly DJ et al. (2014) Inter-hemispheric temperature variability over the past millennium. Nature Climate Change 4: 362-367.

Neukom R, Luterbacher J, Villalba R et al. (2010) Multiproxy summer and winter surface air temperature field reconstructions for southern South America covering the past centuries. Climate Dynamics 37(1-2): 35-51.

Osborne J, Borosova R, Briggs M et al. (2009) Survey for Baseline Information on Introduced Vascular Plants and Invertebrates: South Georgia Introduced Vascular Plants. Surrey: Kew - The Royal Society for the Protection of Birds, pp. 1-157.

Pettigrew TH (1981) The geology of Annenkov Island. British Antarctic Survey Bulletin 53: 213-254.

Reimer R and Reimer P (2004) CALIBomb - Calibration of postbomb C-14 data. Available at: http://www.calib.org.

Rosqvist GC, Rietti-Shati M and Shemesh A (1999) Late glacial to middle Holocene climatic record of lacustrine biogenic silica oxygen isotopes from a Southern Ocean island. Geology 27: 967-970.

Rosqvist GC and Schuber P (2003) Millennial-scale climate changes on South Georgia, Southern Ocean. Quaternary Research 59: 470-475.

Schalke HJWG and van Zinderen Bakker EMS (1971) History of the vegetation. In: Van Zinderen Bakker EM, Winterbottom $\mathrm{JM}$ and Dyer RA (eds) Marion and Prince Edward Islands Report on the South African Biological and Geo-logical Expedition, 1965-1966. Cape Town: A.A. Balkema, pp. 89-97.
Scott L and Hall KJ (1983) Palynological evidence for interglacial vegetation cover on Marion Island, sub-Antarctic. Palaeogeography, Palaeoclimatology, Palaeoecology 41: 35-43.

Sterken M, Roberts SJ, Hodgson DA et al. (2012) Holocene glacial and climate history of Prince Gustav Channel, northeastern Antarctic Peninsula. Quaternary Science Reviews 31: 93-111.

Stockmarr J (1971) Tablets with spores used in absolute pollen analysis. Pollen Spores 13: 615-621.

Stuiver M, Reimer PJ and Reimer RW (2014) CALIB 7.0.2. Available at: http://www.calib.org.

Toggweiler JR, Russell JL and Carson SR (2006) Midlatitude westerlies, atmospheric $\mathrm{CO}_{2}$, and climate change during the ice ages. Paleoceanography 21(2): 1-15.

Unkel I, Fernandez M, Björck S et al. (2010) Records of environmental changes during the Holocene from Isla de los Estados (54.40 S), southeastern Tierra del Fuego. Global and Planetary Change 74(3-4): 99-113.

Van der Putten N and Verbruggen C (2005) The onset of deglaciation of Cumberland Bay and Stromness Bay, South Georgia. Antarctic Science 17(1): 29-32.

Van der Putten N, Mauquoy D, Verbruggen C et al. (2012a) SubAntarctic peatlands and their potential as palaeoenvironmental and palaeoclimatic archives. Quaternary International 268: 65-76.

Van der Putten N, Stieperaere H, Verbruggen C et al. (2004) Holocene palaeoecology and climate history of South Georgia (sub-Antarctica) based on macrofossil record of bryophytes and seeds. The Holocene 14: 382-392.

Van der Putten N, Verbruggen C, Björck S et al. (2012b) Is palynology a credible climate proxy in the sub-Antarctic? The Holocene 22(10): 1113-1121.

Van der Putten N, Verbruggen C, Ochyra R et al. (2009) Peat bank growth, Holocene palaeoecology and climate history of South Georgia (sub-Antarctica), based on a botanical macrofossil record. Quaternary Science Reviews 28: 65-79.

Van der Putten N, Verbruggen C, Ochyra R et al. (2010) Sub-Antarctic flowering plants: Pre-glacial survivors or post-glacial immigrants? Journal of Biogeography 37: 582-592.

Varma V, Prange M, Merkel U et al. (2012) Holocene evolution of the Southern Hemisphere westerly winds in transient simulations with global climate models. Climate of the Past 8: 391-402

Veblen TT, Hill RS and Read J (1996) The Ecology and Biogeography of Nothofagus Forests. New Haven, CT: Yale University Press.

Veblen TT, Burns BR, Kitzberger T et al. (1995) The ecology of the conifers of southern South America. In: Enright NJ and Hill RS (eds) Ecology of Southern Conifers. Carlton: Melbourne University Press, pp. 120-155.

Walton DWH (1976) Dry matter production in Acaena (Rosaceae) on a sub-Antarctic Island. Journal of Ecology 64(2): 399-415.

Watson AJ and Garabato CAN (2006) The role of Southern Ocean mixing and upwelling in glacial-interglacial atmospheric $\mathrm{CO}_{2}$ change. Tellus B 58: 73-87.

Wilce JH (1972) Lycopod spores, I. General spore patterns and the generic segregates of Lycopodium. American Fern Journal 62(3): 65-79.

Young SB and Schofield EK (1973) Pollen evidence for Late Quaternary climate changes on Kerguelen Islands. Nature 245: 311-312. 